\title{
Potential Impact of the Mass Media on Family Planning in an Urban Community in South Western Nigeria
}

\section{Lola V. Adekunle, Isaac O Olaseha and Joshua D. Adeniyi}

Department of Epidemiology, Biostatistics \& Environmental Health, Faculty of Public Health, College of Medicine, Universiy of Ibadan, Ibadan, Nigeria

\begin{abstract}
Context: The role of radio and television message is an important factor in creating and changing the values, ideas and attitudes of people in Public Health. Fertility regulation in Nigeria is still yet to meet the optimum level.

Objectives: The research therefore is designed to assess the role of mass media, radio and television in family planning messages.

Study Design, Setting and Subjects: The study involved 503 females and males of child bearing age at Ife Central District, South Western of Nigeria. Information on respondents socio-economic characteristics family planning practices, their knowledge and attitude, source of information and use of family planning methods including habits and media preference of the respondent were also collected.

Results: Radio was found to be the most common source of information. Fifty-three percent reported that they got family planning messages through the radio as against $10.1 \%$ through the television in spite of the fact that $68.5 \%$ of the respondents had television and $89.1 \%$ had radio. Seventy-two percent of the respondents had never visited family planning clinic. The most favourite programme on T.V. was drama while that of the radio was the news.

Conclusion: The need to intensify and integrate family planning message into television drama and radio news was identified as this could play a significant role in family planning.
\end{abstract}

Key Words: Family Planning Messages, Radio, Television, Mass Media. [ Trop J Obstet Gynaecol, 2004;21:88-90]

\section{Introduction}

The role of Radio and Television in creating awareness and changing the values, ideas and attitudes of people to serious life threatening infections such as AIDS can not be over emphasized. Television and radio have been found useful in sending messages across the nation. Few studies have observed bias among health workers in providing family planning methods to especially the adolescents who constitute almost $45 \%$ of the Nigeria population ${ }^{1-2}$. Recent studies also revealed that perception of family planning and attitudes to contraceptive use is generally low among various reproductive groups in Nigeria ${ }^{3-6}$.

A review of the Nigorian population's donographic patterns in the last docause aganst tho period boweon 1995 and 2000 revealod that fortity foll significanty to $6.2 \%$ but this is still a far cry from the $4.0 \%$ target. Infant mortality rate has risen in the pasi few ycas but crude death rate has remained stagnant at $21.4 \%$ in 1995

${ }^{7-8}$. The current contraceptive prevalence rate of $11 \%$ is a far cry from a targeted rate of $80 \%$ in the National population policy.

The National population policy was promulgated in 1988 to improve the living standards and quality of life of Nigerians by reducing the persistent high level of fertility and population growth and achieving rural urban development. In spite of all efforts, it has been observed that the National Population Policy (NPP) has not been improved much because of the declining fertility not appreciable neither is the welfare significant. This had been attributed to limited availability and poor quality services which lead to high maternal and infant mortality rate, inadequate adolescent out reach and limited contraceptive use ${ }^{10}$. In 1991, Nigerian population census was put at 88.99 million, an increase of 2.7 to 3.3 percent per annum between 1953 and 1991, consequently, the growth rate of the population was found higher than the growth of the economy which is put at $0.5 \%{ }^{\mathrm{in}}$. Above all, average Nigerians still cherish large number of children and childlessness is a strong ground for divorce under the customary law ${ }^{12-14}$. Consequently, this research is designed to access the role of the mass media: radio and television in disseminating family planning messages at Ife Local Government Area of Osun State, South West of Nigeria.

\section{Matorials and Methods}

The study was conducted at lle-lfe, a predominantly Yoruba community and the cradle of Yoruba Urban civilization. The Local Government was created in

Correspondence: Dr. (Mrs.) Lola Adekunle, Department of Epidemiology, Biostatistics \& Environmental Health, Faculty of Public Health, College of Medicine, University of Ibadan, Ibadan, Nigeria 
1989 as one of the 22 Local Governments of Osun State. It has an estimated population of 197, 302 (CC CD 1993).

The people live in extended family compounds. Traditionally, a family compound consists of clusters of houses whose residents share close paternal ties. Polygamy and monogamy are the two types of marriages that flourish in the area. The males are predominantly farmers while most females are petty traders. The inhabitants are Christians, Moslems and adherent of traditional religious practices.

\section{Health Facilities}

There are two hospitals in the area that provide secondary and tertiary care, in addition to five dispensaries, several private clinics, pharmacies and a myriad of patent medicine stores and traditional healing homes.

\section{Sampling Technique}

A stratified multi-stage sampling technique was used to select 503 males and females of childbearing age (15-49 years). Information obtained from the respondents includes family planning practices, assessment of the respondents' knowledge, attitude, source of family planning information, media habits and preferences with regards family planning messages.

\section{Statistical Analysis}

Data was analysed using Epi-Info 6 and SPSS statistical packages. All questionnaires were coded into the computer. Data was cleared using a double entry system. Analysis of data was done using simple percentages and ranking order to summarise source of family planning information.

\section{Results}

The respondents consisted of $48.1 \%$ males and $51.9 \%$ female and $63.2 \%$ were in their active reproductive years. $90 \%$ were married and $57.4 \%$ were monogamists and $42.6 \%$ were polygamists. Based on religion, over half of the respondents were Christians (all Protestants) and only $11 \%$ were Catholics and $30.7 \%$ were Moslem. On literacy, only $19.1 \%$ were illiterate, the rest of the respondents had 1-6 years of schooling (48.5\%) whilst $14.3 \%$ had gone beyond secondary education (See Table 1). On family planning information, $53 \%$ of the respondents reported that they got their family planning messages through the radio, followed by health workers $(15.5 \%)$ posters $(10.5 \%)$ television $(10.12 \%)$ and through music $(6.4 \%)$ and other print media such as pamphlets/ leaflets $(0.6 \%)$, newspaper message $(0.2 \%)$ and town crier $(0.4 \%)$. On accessibility to media; $89.4 \%$ had radio sets while $65.8 \%$ had television sets. News is the most favourite radio programme reported while it was drama on the television. On the use of family planning services, $74.2 \%$ had never used the services while $21.2 \%$ of the respondents had used the services at one time of the other. Majority of the respondents favoured 1-4 children which is the nationally recommended family size per woman. $10.5 \%$ however favoured large family size such as $5-8$ children and $0.5 \%$ favoured $9-12$ children. Nearly half of the couples did not discuss the issue of family planning as husband and wife.

Table 1: Respondents Socio-economic and Demographic characteristics

\begin{tabular}{|c|c|c|c|c|c|}
\hline \multicolumn{6}{|l|}{ Variables } \\
\hline Sex & Male & Female & & & \\
\hline No & 246 & 257 & & & \\
\hline$\%$ & 48.9 & 51.1 & & & \\
\hline Age & $15-24$ & $25-34$ & $35-44$ & $45-54$ & $55+$ \\
\hline No & 48 & 193 & 125 & 60 & 66 \\
\hline$\%$ & 8.9 & 38.4 & 24.8 & 14.9 & 13.1 \\
\hline $\begin{array}{l}\text { Marital } \\
\text { Status }\end{array}$ & Single & Married & $\begin{array}{l}\text { Divorced/ } \\
\text { separated }\end{array}$ & Widowe & \\
\hline No. & 30 & 453 & 16 & 3 & \\
\hline$\%$ & 6.0 & 90.0 & 3.2 & 0.6 & \\
\hline $\begin{array}{l}\text { Types of } \\
\text { Marriages }\end{array}$ & $\begin{array}{l}\text { Monoga- } \\
\text { mous }\end{array}$ & Polygam & & & \\
\hline No & 26.0 & 193 & & & \\
\hline$\%$ & 57.4 & 42.6 & & & \\
\hline Religion & $\begin{array}{l}\text { Moslem/ } \\
\text { Christians }\end{array}$ & (Catholic) & Protestants & Others & \\
\hline No & 151 & 55 & 279 & 14 & \\
\hline$\%$ & 30.7 & 11.0 & 55.6 & 2.8 & \\
\hline
\end{tabular}

Table 2: Respondents Social Class based on Education and Occupation

\begin{tabular}{|c|c|c|c|c|c|c|}
\hline \multicolumn{2}{|c|}{$\begin{array}{l}\text { Variables } \\
\text { Education Illiterate }\end{array}$} & $\begin{array}{l}\text { Primary } \\
\text { /Koranic } \\
150\end{array}$ & $\begin{array}{l}\text { Secon- } \\
\text { dary } \\
151\end{array}$ & \multicolumn{2}{|c|}{$\begin{array}{l}\text { Post } \\
\text { Secondary } \\
72\end{array}$} & \\
\hline$\%$ & D9.1 & & & 14. & & \\
\hline $\begin{array}{l}\text { Years of } \\
\text { Schooling }\end{array}$ & $1-6$ & $7-13$ & Above1? & & & \\
\hline No & 244 & 158 & 67 & & & \\
\hline$\%$ & 48.5 & 31.4 & 13.3 & & & \\
\hline Occupation & $\begin{array}{c}\text { Civil } \\
\text { Servants }\end{array}$ & Artisans & $\begin{array}{l}\text { Tra- Fa } \\
\text { ders }\end{array}$ & $\begin{array}{l}\mathrm{rm}- \\
\mathrm{rs}\end{array}$ & $\begin{array}{c}\text { Trans- } \\
\text { port }\end{array}$ & $\begin{array}{l}\text { Unem- } \\
\text { ployed }\end{array}$ \\
\hline No & 56 & 99 & 169 & 88 & 16 & 42 \\
\hline$\%$ & 11.2 & 19.2 & 33.7 & 6.6 & 3.2 & 8.4 \\
\hline $\begin{array}{l}\text { Ethnic } \\
\text { Origin }\end{array}$ & Yoruba & Hausa & Ibos & & & \\
\hline No & 437 & 29 & 35 & & & \\
\hline$\%$ & 86.9 & 5.8 & 7.0 & & & \\
\hline
\end{tabular}


Table 3: Reported Most Popular Source of message on Family Planning

\begin{tabular}{lccc}
\hline Source & No & $\%$ & Ranking Order \\
\hline Radio & 263 & 53.0 & 1 st \\
Health workers & 76 & 15.3 & 2 nd \\
Poster & 52 & 10.5 & 3 rd \\
Television & 5 & 10.1 & 4 th \\
Mus ic & 2 & 6.4 & 5 th \\
No idea & 26 & 5.2 & 6 th \\
None & 20 & 4.0 & 7 th \\
Pamphlet/leaflet & 3 & 0.6 & 8 th \\
Town crier & 2 & 0.4 & 9 th \\
News & 1 & 0.2 & 10 th \\
Paper/Magazine & & & \\
Public Address & 1 & 0.2 & 10 th \\
system & & & \\
Line cover & - & - & - \\
\hline
\end{tabular}

Table 4: Respondents used of Family Planning Services

\begin{tabular}{lccccc}
\hline $\begin{array}{l}\text { Ever visited family } \\
\text { planning clinic }\end{array}$ & Yes & No & 107 & & \\
& & $\%$ & 21.2 & & \\
& No & No & 373 & & \\
& & $\%$ & 74.2 & & \\
No. of children desire & $1-4$ & $5-8$ & $9-12$ & N/A \\
& No & 170 & 20 & 1 & 191 \\
& $\%$ & 89.0 & 0.5 & 0.5 & 37.9 \\
Do you discuss with & & Yes & No & N/A & \\
Spouse about family & No & 183 & 238 & 12 & \\
planning & $\%$ & 40.4 & 57.0 & 2.6 & \\
\hline
\end{tabular}

\section{Discussion}

The importance of the role of the radio in language communication cannot be over emphasized. The fact that over half of the respondents expressed that radio was the most important source of message on family planning is an indication that the Radio could be used to intensify family planning messages, especially during or shortly after the news. Health workers' influence is also important. So also is the print media and television drama. It is an acknowledged fact that faced with information about a risk to their health, people might be expected to amend their behaviour, habits or change their environment to reduce exposure to the risk. However, evidence has shown that people do not respond in such a rational manner to messages about risk (15-18). Though $89 \%$ of the respondents were found to have favoured limited number of children of at most four, yet only $21.2 \%$ had ever visited family planning clinics. This is in spite of the fact that the majority perceived the radio as an important source of family planning messages. Since news and drama were found to be the most favoured programmes, integrating family planning messages through news and drama may increase further awareness on the need to reduce fertility for effective control of population.

\section{References}

1. Adekunle A. O, Arowojoju A. A.Adedimeji A.A., and Roberts O. A. Adelescent Contraception: Survey of attitudes and practices of Health professionals Afr. $J$. Med. Med. Sci. 2000, 29:247-252.

2. Onwamanu D, Sexual activities of School girls. Adolescents in Nigeria. Adolescents 1982, 17: 81-89.

3. Makinwa- Adebusoye P.K. Sexual behaviour reproductive knowledge and contraceptive use among Urban Nigeria.Int. Fam. Plan. Persp.1992, 18: 67-69.

4. Odesanmi W. O. and Jinadu, Adolescent Sexual behaviour and Condom Use in Ile-Ife Nigeria. Clin. Nurs. Res. 1993, 2: 114-118.

5. Odunjiinrin OMT Sexual activity contraceptive practices and abortion among adolescents in Lagos. Int. J. Gynecol. Obstet. 1991, 34:361 366.

6. Nicholas D. Ladipo O.A. Paxma J.M. and Otolorin E. O. Sexual behaviour, contraceptive practices and reproductive health among Nigeria adolescents. Stud. Fam. Plan.

7. Federal Government of Nigeria (FGN). National Programme of Action for the Survival, Protection and Development of Nigeria. Child. National Planning Commission Lagos 2001.

8. FOS/IRDMII Nigeria Demographic and Health Survey 1990 Fed. Office of Statistics, Lagos.

9. FOS/UNICEF Multiple Indicator christer Survey 1995. Federal office of statistics lagos.

10. UNICEF. Children's and Women's right in Nigerian: A Wake-up Call. Situation Assessment and Analysis, 2001.

11. UNICEF, The progress of Nations, 1998, UNICEF New York.

12. Akande E. O. Women's Health in Nigeria Past, Present and Prospects for the Millenium. Afr. J. Med. Med. Sci. 2000, 29: 7582 .

13. Oyemade A, Status of Women in Family Planning in edited proceeding of the Conference on Nigerian Women and Development (ed) Ogunseye F. A., Awosika K., Dennis CD and Akinkoye O. 1982:221-237. 